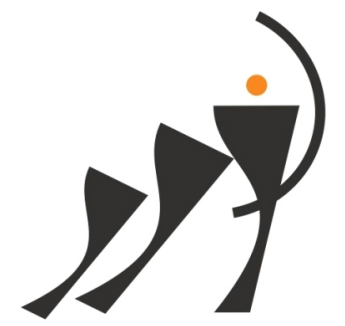

Vol. 6, No. 1, 2018

B A L T I C

J O U R N A L

OF CAREER

EDUCATION

AND $\bullet \bullet$

MANAGEMENT

\title{
Baltic Journal of Career Education
} and

Management
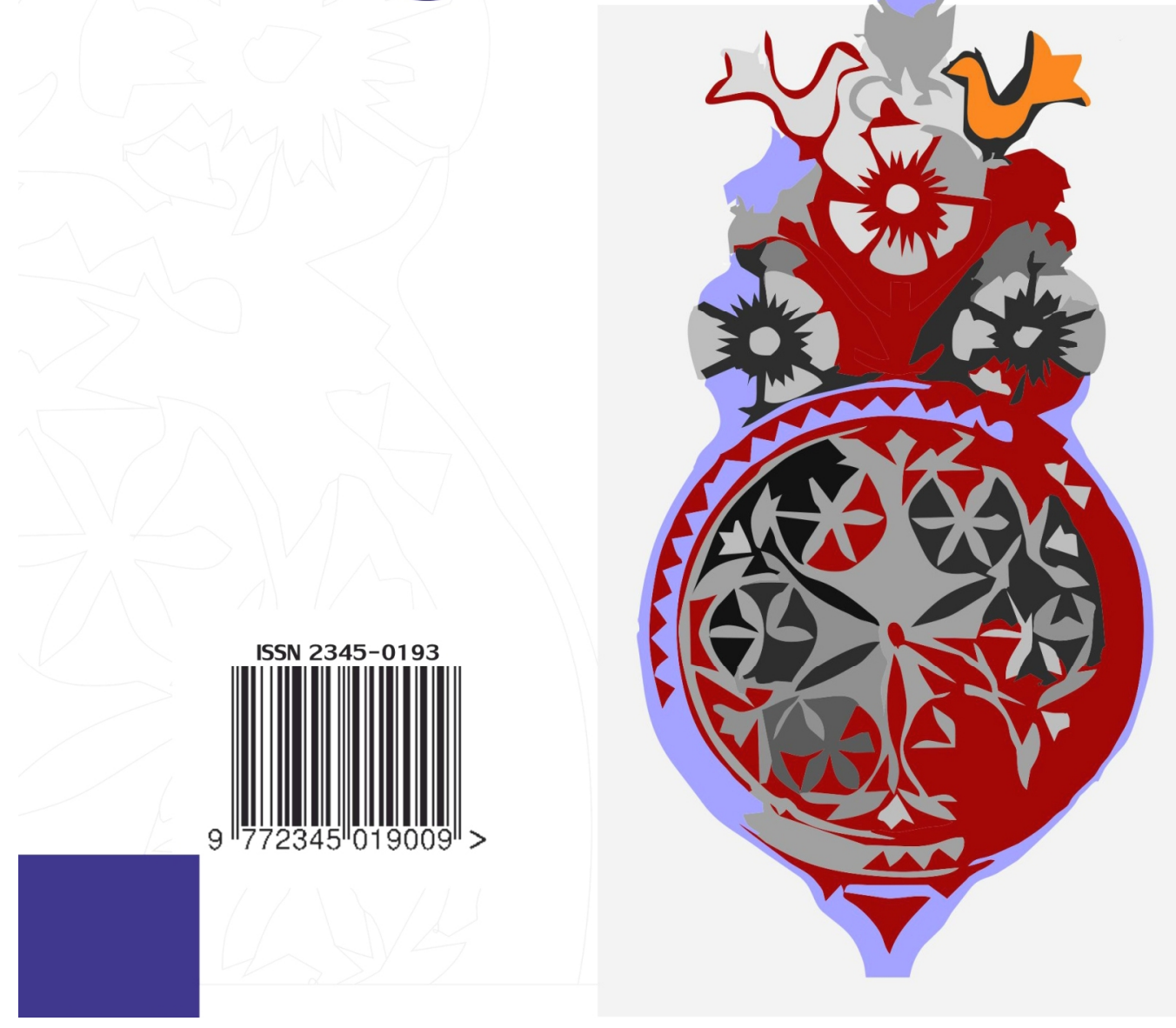
Baltic Journal of Career Education and Management, Vol. 6, No. 1, 2018 ISSN 2345-0193 /Print/, ISSN 2538-7189/Online/

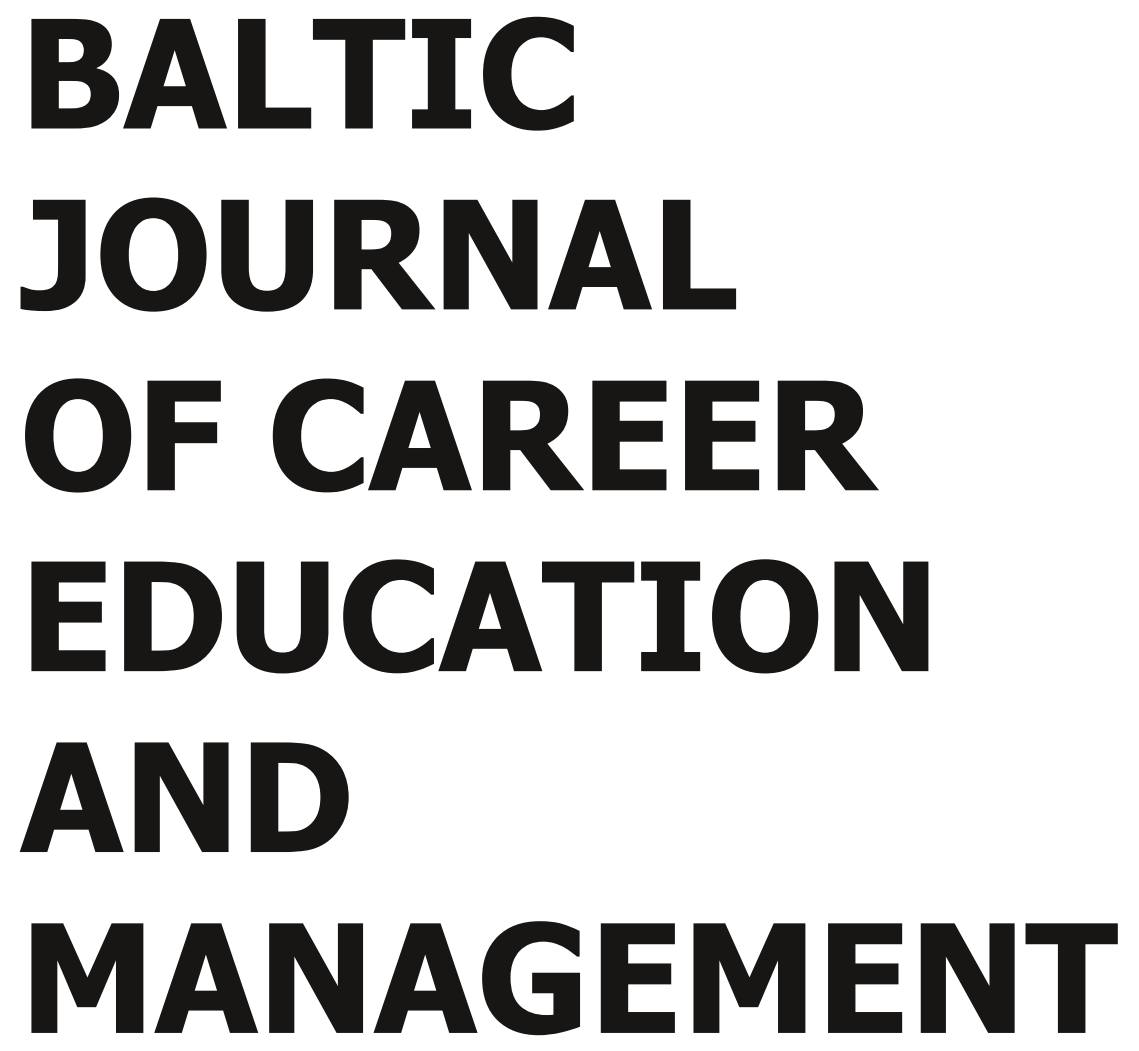

Scientia Socialis Ltd. \& Scientific Methodical Center ",Scientia Educologica“, Lithuania,

The Associated Member of Lithuanian Scientific Society, the Association of Lithuanian Serials, ESHS (European Society for the History of Science), and ICASE (International Council of Associations for Science Education)

The articles appearing in this scientific journal are indexed and abstracted in:

EBSCO

Copernicus Index

Electronic Serials in Lithuania

Research Bible

Open Academic Journals Index (OAJI)

Ulrich's Periodicals Directory / Global Serials

Directory,

Directory of Research Journals Indexing (DRJI)

Global Impact Factor (GIF)

Academic Keys

Scientific Indexing Services (SIS)
European Reference Index for the Humanities and the Social Sciences (ERIH PLUS)

Information Matrix for the Analysis of Journals (MIAR)

Turkish Education Index (TEI)

CIRC (Clasificación Integrada de Revistas Científicas)

Academic Resource Index (ResearchBib)

World Catalogue of Scientific Journals (WCOSJ) 
Publisher

Scientia Socialis Ltd. in Cooperation with Scientific Methodical Center „Scientia Educologica“, Lithuania, the Associated Member of Lithuanian Scientific Society, the Association of Lithuanian Serials, European Society for the History of Science (ESHS) and International Council of Associations for Science Education (ICASE)

Editor-in-Chief

Dr., Assoc. Prof. Dalia Augienė, University of Siauliai, Lithuania

Editorial Board

Dr., Prof. Metka Kordigel Aberšek, University of Maribor, Slovenia

Dr. Teodor Krasimirov Gergov, South-West University "Neofit Rilski”, Bulgaria

Dr., Prof. Vincentas Lamanauskas, University of Siauliai, Lithuania

Dr., Assoc. Prof. Labby Ramrathan, University of KwaZulu-Natal, South Africa

M.Ed. Judita Stankutė, SMC "Scientia Educologica", Lithuania

Dr., Assoc. Prof. Gunārs Strods, Rezekne Academy of Technologies, Latvia

Copyright of this issue is the property of Scientia Socialis Ltd., Lithuania. By virtue of their appearance in this open access journal, articles are free to use, with proper attribution, in educational and other non-commercial settings.

Baltic Journal of Career Education and Management is an international, periodical, double-blind peer review and open access scientific journal, issued by Scientia Socialis Ltd. in Cooperation with SMC „Scientia Educologica“.

Index Copernicus (ICTM Value): 73.92 (2015).

ICDS (Secondary Composite Index Broadcasting): 3.0

Global Impact Factor (GIF): 0.654 (2015).

ICDS: 3.2 (2018).

\section{Address:}

Scientia Socialis

Donelaičio Street 29, LT-78115 Siauliai, Lithuania

E-mail: $\quad$ bjcem.journal@gmail.com

Phone: $\quad+37068795668$

WEB page: http://www.scientiasocialis.lt/bjcem 